\title{
Diagenesis and its influence on reservoir quality and oil-water relative permeability: A case study in the Yanchang Formation Chang 8 tight sandstone oil reservoir, Ordos Basin, China
}

https://doi.org/10.1515/geo-2019-0004

Received November 15, 2018; accepted January 10, 2019

\section{Introduction}

Recently, due to the considerable resources available, unconventional tight sandstone reservoirs have gradually become the main target of oil and gas energy development [1]. However, poor physical properties, small throats, complex pore structures and strong heterogeneity of tight sandstone can bring a series of complex problems for oil and gas exploration and development $[2,3]$. The detailed evaluation and description of the characteristics of reservoir quality, including porosity, permeability, movable fluid saturation, and oil-water relative permeability, can identify the origin of different reservoir qualities by analyzing diagenesis; these steps are the keys to predicting the dominant reservoirs and efficiently exploring and developing tight oil and gas. In the process of oil production by water injection, clearly understanding the characteristic of pore structure, fluid distribution and two-phase fluid dynamic migration is especially important as the basis for remaining oil studies and enhancing oil recovery $[4,5]$. Reservoir quality is primarily controlled by the microscopic pore morphology and structural features. A large number of research studies were conducted pertaining to pore structure in tight sandstone reservoirs [6-8]. Thin sections, scanning electron microscope (SEM) high-pressure mercury injection (HPMI), nuclear magnetic resonance (NMR), X-ray computer tomography (XCT) and other qualitative or quantitative charac-

Zhaomeng Yang, Changjun Shui, Zhong Yu: Second Oil production Plant, Changqing Oil field Company, CNPC, Qing yang, 745000, China

Zhufeng Wang: Kuqa Oil and Gas Development Project Department, Tarim Oilfield Company, CNPC, Korla, 841000, China Yulin Cheng: State Key Laboratory of Oil and Gas Reservoir Geology and Exploitation, Southwest Petroleum University, Chengdu, 610500, China
610500, China
^Corresponding Author: Meng Wang: State Key Laboratory of Oil and Gas Reservoir Geology and Exploitation, Southwest Petroleum University, Chengdu, 610500, China
Keywords: Maling Oilfield; Chang 8 sandstone; tight oil reservoir; diagenesis; permeability 
terization techniques have been applied to describe and evaluate the pore structure [9-13].

The purpose of studying the influencing factors of reservoir quality is to better guide the exploration and exploitation of tight oil. Many studies have found that the same diagenetic facies usually have similar characteristics in their components, pores structure and diagenesis evolution [14]; when these characteristics were noticed, many practical studies were carried out on high quality reservoir prediction by correlating the diagenetic facies to well logs. Predictive models based on probabilistic neural networks (PNN) $[15,16]$ and an artificial neural network (ANN) were also effective $[17,18]$. Two major problems need to be solved before quality prediction is possible; one is how to divide diagenetic facies according to reservoir composition, structure and diagenesis, and the other is to clarify the formation mechanism of reservoir quality corresponding to different diagenetic facies, to identify the diagenetic facies favorable for reservoir development.

The Chang 8 sandstone of the Yanchang Formation in the Maling Oilfield is the main crude oil production layer in the Ordos Basin with a large distribution of oil layers and low porosity, low permeability and strong heterogeneity [19]. Early studies have confirmed the influence of sedimentary facies distribution and diagenesis [20]. Although some scholars have discussed the origin of tight reservoirs [21], most research has been based on the general analysis of all types of samples, which is not conducive to clarifying the differences in reservoir quality and fluid seepage characteristics. Therefore, it is necessary to find an effective research method for evaluation of classification. The diagenetic facies is a direct reflection of the lithology and physical characteristics of the reservoir; hence, classification based on diagenesis can effectively classify the reservoir, which facilitates the detailed study of reservoir quality evaluation and seepage.

Based on the study of the petrological and pore structure characteristics, the Chang 8 reservoir was divided in six diagenetic facies. Comprehensive analysis of three diagenetic facies of reservoir was carried out based on the pore structure, movable fluid properties and two-phase seepage characteristics. The effects of diagenesis on reservoir quality and oil-water relative permeability are illustrated. The main purpose of this paper is to establish an effective reservoir classification method to conduct a targeted analysis on the diversity of reservoir quality and seepage mechanisms.

\section{Geological background}

The Maling Oilfield in the southwest of the Ordos Basin is the earliest developed oilfield in the basin. This oilfield is a reservoir bearing structural-lithologic traps and oil with a regional area of approximately $1000 \mathrm{~km}^{2}$ [19]. The structure is located in the southwest of the Yishan Slope, controlled by a western thrust belt. The Tianhuan depression, Yishan Slope and Weibei Uplift represent the four tectonic units, and the structure in the study area presents a unicline characterized by a westward low and eastward high and a low dip angle that is less than $1^{\circ}$ (Figure $1 \mathrm{~A}$ ). A series of near east - west trending, low amplitude, small nose-like uplifts are developed locally; faults and folds are not developed and the tectonic conditions are stable [22, 23]. The Triassic-age Yanchang Formation is the main oil layer. The sedimentary period of the Yanchang Formation mainly consists of continental facies in a sedimentary depression lake basin (Figure 1B) [24, 25]. The formation can be divided into 10 oil layers from top to bottom (i.e., Chang 1-Chang 10 layer). The thickness of the Chang 8 Formation is generally $70-100 \mathrm{~m}$ (Figure 1C). The formation's deposition source from its sedimentary period came from the northeast, northwest, west and southwest cardinal directions with typical shallow-water delta sedimentary characteristics (Figure 1C) [26, 27]; the main reservoir developed in a delta plain distributary channel and the delta's underwater distributary channel and mouth bar, which has a thickness of approximately 10 to $20 \mathrm{~m}$. The reservoir lithology is mainly gray silty sandstone and fine sandstone. The Chang 8 reservoir is a typical low porosity and low permeability reservoir [28]. However, with the deepening of development, relatively high porosity and permeability reservoir characteristics have been discovered under the entire tight sandstone background. These sweet spots formed a serious high quality reservoir, which is the focus of future exploration and development.

\section{Sample and method}

In this study, approximately 100 core plugs were collected from 15 bore wells in the Maling Oilfield (Figure 1B). All of the sample parameters were analyzed at the State Key Laboratory of the Southwest Petroleum University.

Porosity and horizontal permeability tests were performed on all core plugs with a Low-Permeability Gas Measurement 700 unit made by Sanchez Technologies under a net of confining pressures of $5 \mathrm{MPa}$. In addition, some data were provided by the Institute for Geological Research of 

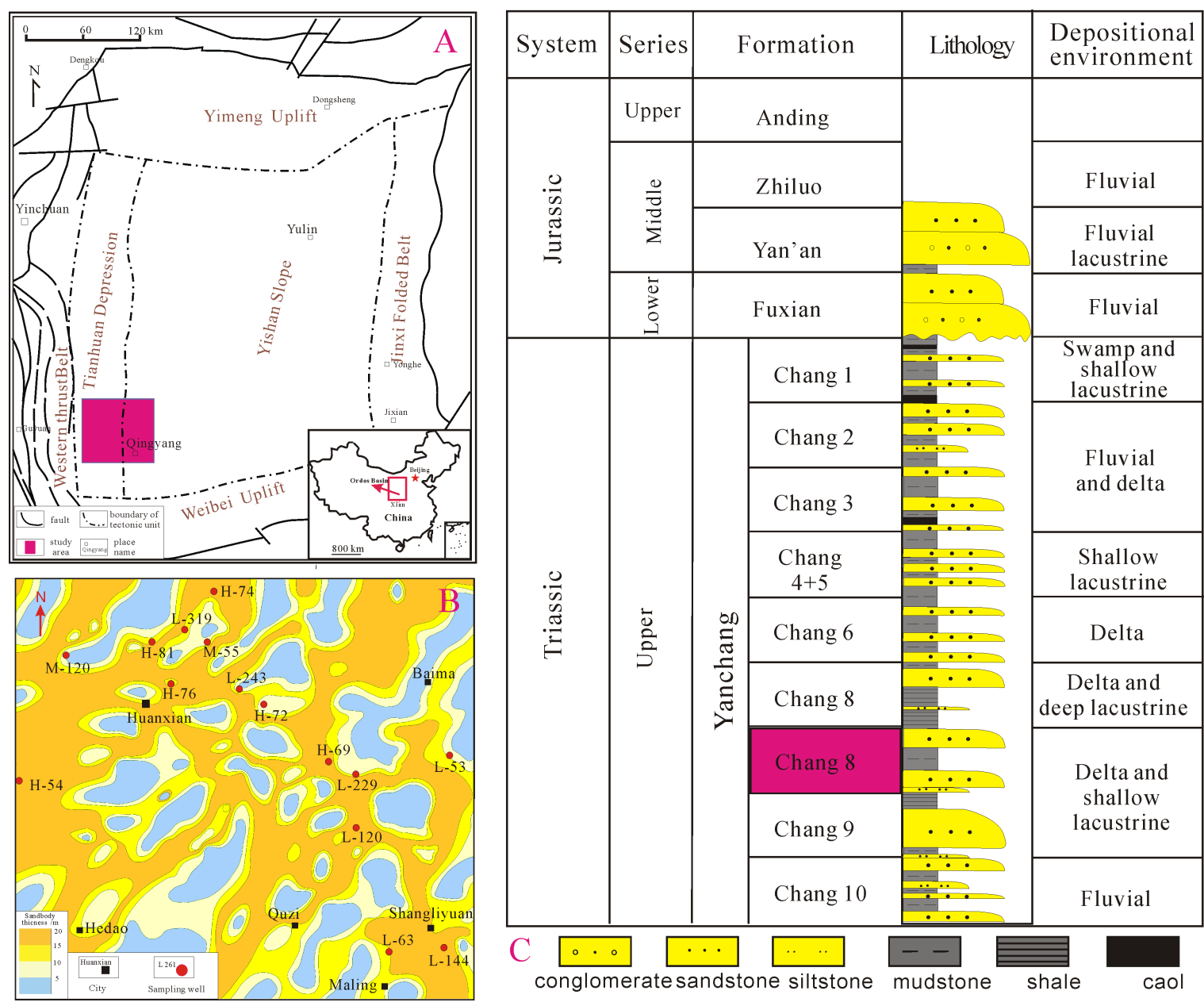

Figure 1: (a) Location of structural units and the Maling Oilfield in the Ordos Basin. (b) Sandbody distribution and sampling well location (c) Lithologic section for the study area showing the location of the Chang 8 interval within the Yanchang Formation (modified after [26]).

the Second Oil Extraction Factory of the Changqing Oilfield.

Each plug has been polished for thin section analysis and prepared by vacuum impregnation with red epoxy resin. Rock mineralogy, diagenetic features, pore characteristics and cements were analyzed using an LV100PO polarized optical microscope.

Different diagenetic facies have been divided out based on the results obtained from the thin sections; 12 samples of three typical diagenetic facies in reservoir development were selected to perform scanning electron microscope on with a Quanta 450 ESEM, which is useful for the identification clays and pore characteristics.

High pressure mercury injection (HPMI), nuclear magnetic resonance (NMR) and oil-water relative permeability measurements were performed on the aforementioned 12 samples.

The HPMI measurements were conducted with a Quanta chrome Poremaster-60 Mercury Injection Appara- tus and relevant parameters, such as capillary pressure curves, threshold pressure, the maximum pore radius, the medium pore throat radius, and the maximum mercury saturation were obtained.

NMR analysis was performed on the plug samples under $100 \%$ saturated and centrifuged conditions (2.07 MPa). The NMR T2 distributions were measured at $25^{\circ} \mathrm{C}$ using a MacroMR12-150H-I nuclear magnetic resonance instrument. The test parameters of the apparatus were set as a receiver delay (RD) of $500 \mathrm{~ms}$, echo time (TE) of $3.5 \mathrm{~ms}$ and number of echoes of 400 .

Oil-water relative permeability measurement was performed with a HAG-250 Permeability Tester; this analysis is important for quantitative characterization of oil and water two-phase flow. 


\section{Results and discussion}

\subsection{Diagenetic facies and pore structure}

Grigsby and Langford (1996) first proposed the concept of diagenetic facies to describe diagenetic heterogeneity in sandstone reservoirs [29]. Zou redefined the concept based on extensive sandstone reservoir research in China; they thought diagenetic facies were the result of diagenetic and structural the processes interacting with sedimentary features [30]. Regardless of their definition, the diagenetic facies is a comprehensive reflection of diagenesis types and strength, diagenetic minerals, and other information [30, 31]. Therefore, it is widely used to illustrate the diagenetic history, evaluate reservoir quality, explain the genesis of tight sandstone and predict 'sweet spots' in recent years [30, 32-34].

Generally, diagenetic facies are classified on the basis of such parameters as grain size, authigenic minerals, sorting, clay matrix content, and pore structure [34]. A large number of research publications focus on the classification of diagenetic facies [33, 35]. The tight sandstone in the Ordos Basin is one of these hot spots and some new achievements have been obtained through the study of the sandstone in Chang 3, Chang 7 and Chang 8, the major oil layer of Upper Triassic Yanchang formation [32, 36, 37].

According to the microscopic observation of the polished thin sections, the lithology of the reservoir rocks sandstone is dominated by lithic arkose and feldspathic litharenite followed by litharenite. Cements are dominated by clay and carbonate minerals. Based on lithological characteristics, such as the texture, composition, type and degree of diagenesis, diagenetic minerals, and pore structure characteristics, the Chang 8 sandstone has been divided into six diagenetic facies (Figure 2).

Facies I: Weakly compacted and weakly cemented, high primary porosity facies (Figure 2a).

This facies is characterized by weak compaction, low cement minerals, and low matrix content. Primary intergranular pores have been well-preserved, and there are certain feldspar and lithic dissolution pores. The sandstone is porosity-cemented and the intergranular contact is mainly a point contact.

Facies II: Weakly compacted and intensely chlorite cemented, high primary porosity facies (Figure $2 b$ ).

Chlorite cementation is intensely developed, present as grain coating around quartz or feldspar grains; the content of chlorite is generally more than $3 \%$. Pore space is mainly intergranular pores and partly intergranular or intragranular dissolution pores. Authigenic microquartz ce- mentation is common in pores, but its content is generally not more than $2 \%$. Chlorite development has two effects: on the one hand, due to its growth on the particle surface, the siliceous cementation loses the mineral growth crystal nucleus and quartz overgrowth is inhibited; on the other hand, the primary pores can be well-preserved, and the chlorite becomes a favorable indicator for the development of high porosity reservoirs.

Facies III: Intensely compacted and weak dissolution facies (Figure 2c).

Compaction leads to a large number of pore loss; the proportion of primary pores is less than $2 \%$. These pore spaces provide a channel for the migration of dissolution fluid. Dissolution of feldspar and rock debris contributes to the improvement of reservoir quality and dissolution mainly develops at the grain edge and inside. As the cementation after dissolution is weak, the pores have been well-preserved.

Facies IV: Weak dissolution and intensely cemented facies (Figure 2d).

Dissolution development, soluble feldspar and rock debris content is high; potassium feldspar dissolution is the most common. The dissolution pore types are the same as in the type III facies; however, unlike the type III facies, the authigenic mineral cementation in the pores is intense, especially the ferrocalcite cement, which blocked almost all of the pores.

Facies V: Intensely compacted facies (Figure 2e).

The sandstone pore loss due to intensely compaction is more than $85 \%$ and widely developed in the siltstone and fine sandstone. In the sandstone rich in rigid rock debris, diagenesis is characterized by feldspar and debris grains that were broken under compaction, while in the sandstone rich in plastic rock debris and matrix, diagenesis is shown as the plastic deformation of mica, phyllite and slate rock debris. Due to the influence of early intense compaction, the degree of development of the cementation and porosity are very low.

Facies VI: Intensely calcite cemented facies (Figure 2f).

Cementation of early calcite and late ferrocalcite notably destroyed porosity. The content of calcite cementation is generally greater than $16.5 \%$, accompanied by feldspar kaolinization, calcite metasomatic, dissolution is undeveloped. Pores are extremely rare.

The porosity of all samples is generally less than $10 \%$ and the permeability is less than $10 \mathrm{mD}$ (Figure $2 \mathrm{~g}$ ). The porosity of the facies I sandstone is relatively high, with residual intergranular pores being well-preserved, and developing of feldspar and debris dissolution pores; the rock cementation is weak, and the porosity ranges from 8.86 to $11.2 \%$ with an average of $9.8 \%$, while the permeabil- 

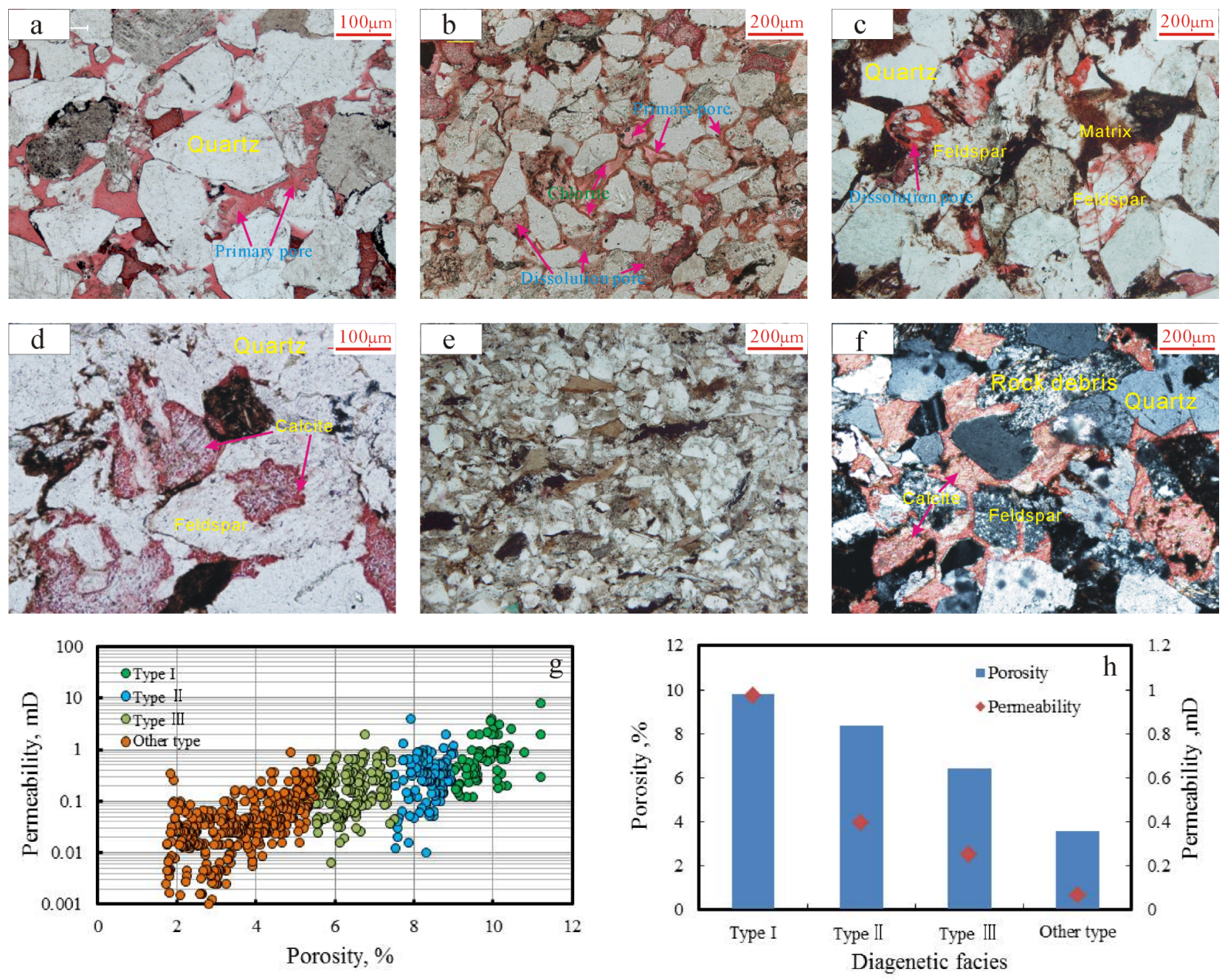

Figure 2: Microscopic characteristics and porosity/permeability parameters of each diagenetic facies. (a) H-54, 2807.52 m; (b) H-81, 2484.42 m; (c) H-69, 2347.06 m; (d) L-63, 2180.11 m; (e) L-63, 2180.11 m; (f) L-53, 2117.26 m. (g) Correlation between porosity and permeability of different diagenetic facies type; (h) distribution of average porosity and permeability of different diagenetic facies type.

ity ranges from $0.12 \sim 8 \mathrm{mD}$ with an average of $0.971 \mathrm{mD}$ (Figure 2h). Facies II sandstone shows characteristic of intense chlorite cementation had primary intergranular pore development, weak dissolution, and partial calcareous and siliceous cementation ; its porosity ranges from 7.31 to $8.95 \%$ with an average of $8.34 \%$, and permeability ranged from 0.01 to $4.02 \mathrm{mD}$ with an average of $0.393 \mathrm{mD}$ (Figure 2h). Because of the intense compaction and cementation of the facies III sandstone, primary pores are completely destroyed and pores are mainly dissolution pores; porosity ranges from 5.34 to $7.26 \%$ with an average of $6.39 \%$; permeability ranges from 0.006 to $2.13 \mathrm{mD}$, with an average of $0.251 \mathrm{mD}$ (Figure $2 \mathrm{~h}$ ).

The other three facies are dense due to intense compaction, calcite cementation after dissolution, or early intense calcite cementation, and extremely low pore development degree. The average porosity of $3.58 \%$ and an av- erage permeability of $0.066 \mathrm{mD}$ (Figure $2 \mathrm{~h}$ ), which is lesser than the lower limit of the reservoir physical properties with no industrial value.

\subsection{Reservoir quality of different diagenetic facies}

In addition to porosity and permeability, the reservoir quality should also include pore structure characteristics and fluid flow characteristic. The MICP provides entry pressure, displacement pressure and pore-throat radius distribution [38]; pore size distribution and movable fluid parameters obtained from NMR test can effectively describe the distribution of movable fluid and relative size of the flowing pore space in porous media [10, 39]. Parameters from the oil-water relative permeability curve makes 
it clear to analyze the two-phase flow state and remaining oil evaluation in different reservoirs [40, 41]. The results show that there are obvious differences between the three typical reservoir sandstone diagenetic facies (Table 1, Figure 3):

Primary and secondary pores are developed in the facies I sandstone, and their throats are bundle-shaped and flake-shaped (Figure 3a-1). The displacement pressure of the mercury injection test is $0.47 \mathrm{MPa}$ with a median injection pressure of $4.15 \mathrm{MPa}$, and the median pore radius is $0.17 \mu \mathrm{m}$ (Figure 3a-2). The nuclear magnetic resonance test shows a movable fluid saturation of $60.58 \%$ (Figure 3a3). The oil phase's relative permeability was 0.521 under a bound water state, and $\mathrm{Kro}=\mathrm{Krw}$ when the water saturation was $48.08 \%$; at the residual oil state, water phase permeability was 0.661 , and the water saturation reaches 61.15\% (Figure 3a-4).

Similar to the facies $I$, the primary and secondary pores of facies II sandstone are developed, but the pore throats appear in the form of a laminated or neck shape (Figure 3b-1). The displacement pressure is $1.47 \mathrm{MPa}$ and the median injection pressure reaches $5.52 \mathrm{MPa}$. The corresponding median pore radius is $0.13 \mu \mathrm{m}$ (Figure $3 \mathrm{~b}-2$ ) and movable fluid saturation of the sandstone is $52.35 \%$ (Figure 3b-3). The oil-water relative permeability test shows that the oil phase has a relative permeability of 0.367 in the bound water state when the water saturation reaches $53.06 \%$, Kro=Krw, at the residual oil state, the water saturation reaches $60.90 \%$, and the water phase permeability is 0.194 (Figure $3 b-4$ ).

Compared with the facie $I$ and facie II, the pore development degree of III facies is low, and the pore connectivity is poor; the pore throats are mainly curvilinear (Figure 3c-1). The displacement pressure of this type of facies is the highest, $2.63 \mathrm{MPa}$, with a median pressure of $9.88 \mathrm{MPa}$, and the median radius is $0.07 \mu \mathrm{m}$ (Figure 3c-2). The NMR test showed a dynamic fluid saturation of $40.25 \%$ (Figure 3c-3). The oil-water relative permeability test showed that under the irreducible water saturation state, the relative permeability of the oil phase was 0.486 , and the water saturation was $58.29 \%$ when Kro=Krw. Under the residual oil state, the water saturation was $61.20 \%$, and the water phase permeability was 0.212 (Figure 3c-4).

It is obvious that with the decrease in porosity and permeability, the pore structure property worsens, the bound water saturation increases, and the movable fluid saturation decreases. The characteristics of the "oil-water twophase co-flowing zone" in the relative permeability curve shows that the co-flowing zone area is facies I $>$ II $>$ III, the Kro=Krw point value of facies $I$ sandstone is the highest, and the facies II $\approx$ III (Figure 4 ). Test results show the fa- cies I sandstone has the best seepage property followed by the facies II. It is clear that the poor pore structure leads to a stronger interference of water on the oil phase flow, which is not conducive to enhanced oil recovery. The water saturation of these three reservoir sandstones is approximately $60 \%$ at a residual oil state, which means that when the water saturation reaches $60 \%$, the crude oil will completely loose its flow capacity (Figure 4).

\subsection{Controls on the reservoir quality}

The shallow water delta and the shore near shallow lake sediments are widely developed during the deposition of the Chang 8 Formation. The three main reservoirdeveloped diagenetic facies are formed in the underwater distributary channel and the mouth sand bar body; diagenesis alteration after deposition generates the differences in reservoir quality [20].

\subsubsection{Reduced or enhanced porosity}

The effect of diagenesis on porosity is mainly reflected in the mechanical compaction and cementation [42], and the enhancement of porosity by dissolution [43]. The compaction effect is characterized by discharge of water in the pores and water between the clay mineral layer from the sediment, and the clastic particles are closely arranged, which leads to the decrease in porosity and permeability. The cementation of the Chang 8 sandstone causes destruction of pores by carbonate/siliceous cement, and clay minerals. Calcite has the highest proportion among these cements. The volume of calcite ranges from $1.3 \%$ to $36.5 \%$, with average of $8.55 \%$.

Based on the observation and particle size analysis of the thin sections, the original porosity (OP) of the sandstone was calculated using the formula proposed by Beard and Weyl (1973) [44]. The value ranges from 35.4\% to $39.8 \%$, with an average of $38.2 \%$, which combined with compaction porosity loss (COPL), formula Eq. (1), and cementation porosity loss (CEPL) formula, Eq. (2) [42, 45], to quantitatively evaluate the factors controlling the porosity of each diagenetic facies.

$$
\begin{gathered}
C O P L=O P-\frac{(100 \times I G V)-(O P \times I G V)}{(100-I G V)} \\
C E P L=(O P-C O P L) \times \frac{C E M}{I G V}
\end{gathered}
$$$$
I G V=\text { intergranularporespace }+C E M
$$ 
Table 1: Pore structure and petrophysical property test result of various diagenetic facies sandstones

\begin{tabular}{|c|c|c|c|c|c|c|c|c|c|c|c|c|c|c|}
\hline \multirow{3}{*}{ No. } & \multirow{3}{*}{ type } & \multirow{3}{*}{$\Phi$} & \multirow{3}{*}{ K } & \multirow{2}{*}{\multicolumn{4}{|c|}{$\begin{array}{c}\text { Capillary pressure } \\
\text { curve }\end{array}$}} & \multirow{3}{*}{$\begin{array}{l}\mathrm{NMR} \\
\mathrm{S}_{w m}\end{array}$} & \multicolumn{6}{|c|}{ Relative permeability curve } \\
\hline & & & & & & & & & \multicolumn{2}{|c|}{$\begin{array}{l}\text { irreducible wa- } \\
\text { ter satura- } \\
\text { tion } \\
\text { condition }\end{array}$} & \multicolumn{2}{|c|}{$\mathrm{Kro}=\mathrm{Krw}$} & \multicolumn{2}{|c|}{$\begin{array}{l}\text { residual oil sat- } \\
\text { uration } \\
\text { condition }\end{array}$} \\
\hline & & & & $\mathrm{P}_{d}$ & $P_{50}$ & $\mathrm{R}_{50}$ & $\mathrm{~S}_{H g}$ & & $\mathrm{~S}_{w i}$ & Kro & $\mathrm{S}_{w}$ & $\begin{array}{l}\text { Kro/ } \\
\text { Krw }\end{array}$ & $\mathrm{S}_{w}$ & Krw \\
\hline H54 & $I$ & 10.5 & 0.852 & 0.47 & 4.15 & 0.17 & 90.35 & 60.58 & 40.15 & 0.521 & 48.13 & 0.209 & 61.15 & 0.661 \\
\hline H81 & II & 8.6 & 0.515 & 1.47 & 5.52 & 0.13 & 78.56 & 52.35 & 47.54 & 0.367 & 53.06 & 0.071 & 60.90 & 0.194 \\
\hline H69 & III & 6.8 & 0.218 & 2.63 & 9.88 & 0.07 & 80.25 & 40.25 & 56.13 & 0.486 & 58.29 & 0.058 & 61.20 & 0.212 \\
\hline
\end{tabular}

$\bar{\Phi}$ : porosity, \%. K: permeability, mD. $\mathrm{P}_{d}$ : threshold pressure, MPa. $\mathrm{P}_{50}$ : median pressure, MPa. $\mathrm{R}_{50}$ : median radius, $\mu \mathrm{m}$. $\mathrm{S}_{\mathrm{Hg}}$ : mercury saturation, \%. Swm: saturation of mobile fluid, \%. Swi: irreducible water saturation, \%. $\mathrm{S}_{w}$ : water saturation, $\%$.

OP: original porosity, CEM: intergranular cement, IGV: intergranular volume

In general, the porosity reduction caused by compaction exceeds that caused by cementation. The average porosity loss by compaction of facies I, II and III are $23.5 \%$, $26.4 \%$ and $26.5 \%$, respectively (Figure 5). Meanwhile, the average porosity loss by cementation of facies I, II and III are $5.8 \% 7.9 \%$ and $12.3 \%$, respectively. Intense cementation and compaction of the remaining three facies resulted in serious damage to the pore structure, reducing the residual intergranular pore volume of sandstone to less than $4 \%$.

It is clear that early intense compaction resulted in approximately the same degree of reduction of the original porosity for various sandstones. The difference in the degree of later cementation results in varying degrees of porosity reduction of each facies type (Figure 5).

In some samples of the Chang 8 sandstones, we found bitumen in the pores. This phenomenon indicates the presence of hydrocarbon emplacement. Hydrocarbon emplacement leads to the entry of fluid, rich in organic acids, into the pore system which inhibits the cementation in inorganic diagenetic environments and promotes the dissolution of feldspar and debris, forming secondary pores [46]. There are different degrees of dissolution in pore formation in the three facies, and the pore enhancement ranges from $0.5 \%$ to $7.3 \%$. Among these facies, the facies I and II facies sandstone mainly exhibit dissolution along the edge of a primary pore. Meanwhile, for the facies III, the dissolution mainly occurs on the skeleton particles, due to the intense porosity loss caused by the early compaction and cementation. The intensity of the dissolution determines whether it can be an effective reservoir.

\subsubsection{Different influences on permeability}

The difference in permeability of each diagenetic facies is due to the difference in microscopic pore structure and clay minerals.

The comprehensive effect of compaction and cementation reduces the porosity and forms different pore structure types. The weaker the compaction is, the lesser the influence of cementation is. Stronger the dissolution, the better the primary pores and throats are preserved and corresponding to the less complexity of the pore structure and higher permeability (Figure $2 \mathrm{~g}$ ). Conversely, sandstones that have undergone complex diagenesis will exhibit poor porosity and permeability, which is not conducive to oil seepage.

As the clay minerals are mainly present along the wall of the pores and throats, the clay plays an important role in influencing the fluid seepage. In the main reservoir diagenetic facies, the faciesI andstone has a low degree of development of clay; The facies II sandstone is enriched in chlorite. The chlorite is present as grain coatings or pore lining, with a thickness ranging from $1 \mu \mathrm{m}$ to $18 \mu \mathrm{m}$, and an average of $4.5 \mu \mathrm{m}$ (Figure $6 \mathrm{a}$ ). The facies III sandstone has characteristics illite development, mainly present in the form of flakes and silky grain (Figure 6b, c). Illite is mainly derived from the high temperature alternation conversion of other clay minerals and by-products of feldspar dissolution.

Due to the presence of chlorite and illite, the effective radius of seepage pore is reduced, and the clay minerals increase the internal specific surface area of the rock. Which enhances the sandstone's binding capacities to the fluid (Figure 6f, g). Therefore, facies II and III sandstone exhibit a relatively poor permeability than facies I, in both absolute permeability and relative permeability test (Figure $2 \mathrm{~g}$, 

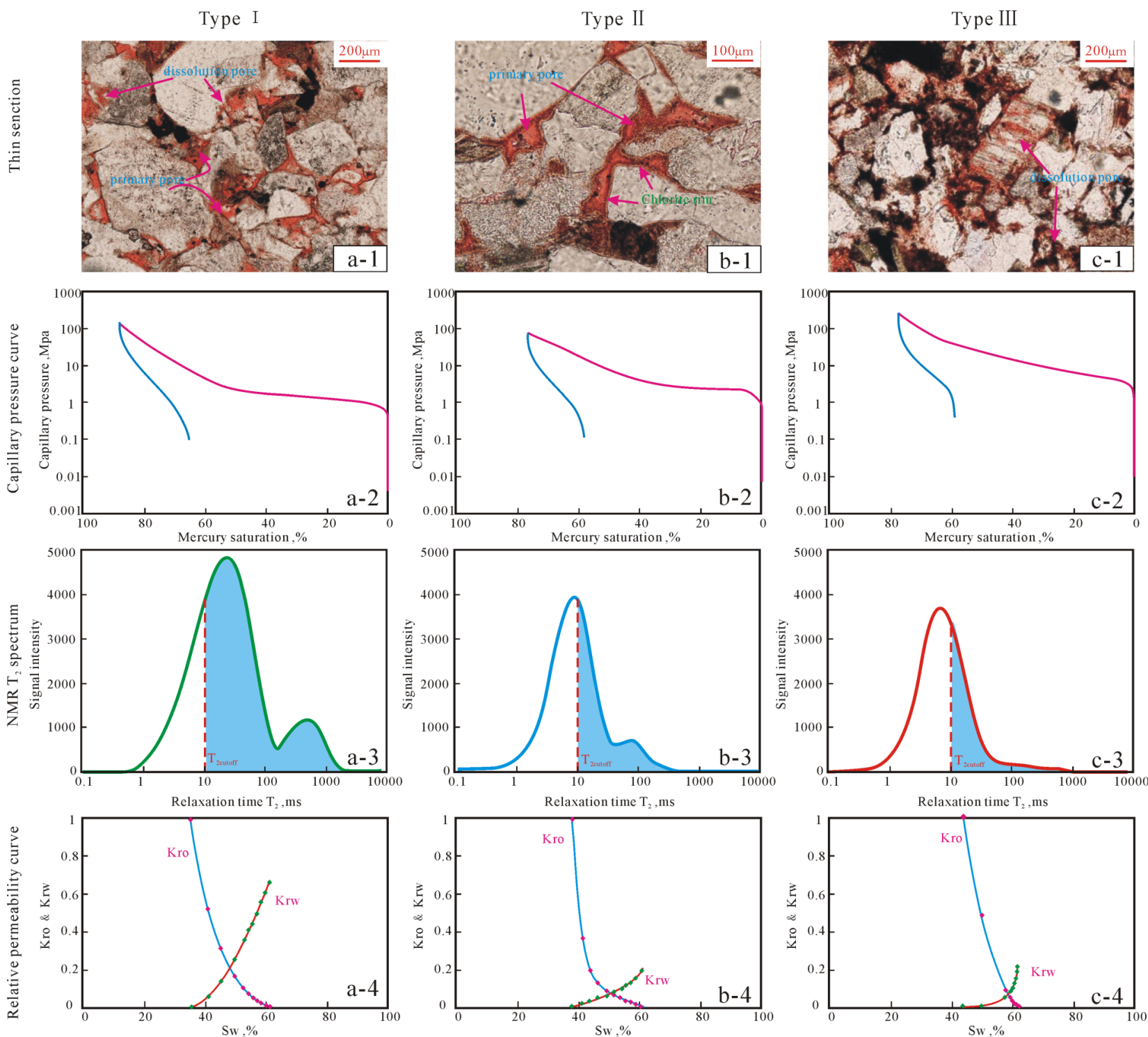

Figure 3: Microscopic pore structure and macroscopic petrophysical property of various diagenetic facies sandstone. (a). Facies $I$, H54, 2807.52 m; (b). Facies II, H81 2484.42 m; (c). Facies III, H69, 2347.06 m.

h; 3a-4, b-4, c-4). Note that although the primary porosity of both facies II and I are well preserved (Figure 6e), the development of chlorite in the facies II sandstone seriously damages to the permeability (Figure 6f).

\section{Conclusions}

To understand the control factors of reservoir quality and seepage property of tight sand oil reservoirs, we take the Chang 8 reservoir in the Maling Oilfield in the Ordos Basin as an example. Thin section, SEM, HPMI, NMR and wateroil relative permeability tests were performed on represen- tative samples to analyzed the features of lithological and pore structure and fluid mobility. Some new insights are summarized as follows.

1. The Chang 8 sandstone exhibits low porosity and low permeability. The intense compaction leads to the general densification of sandstone during the early diagenesis stage. Different degree of carbonate cementation and dissolution in a later stage leads to the differentiation of reservoir quality and promotes the formation of different diagenetic facies. Facies I and II have contributed to better reservoir development.

2. Diagenesis reduces the porosity and changes the microscopic pore structure of the sandstone. The more complicated the pore structure, the worse the seepage prop- 


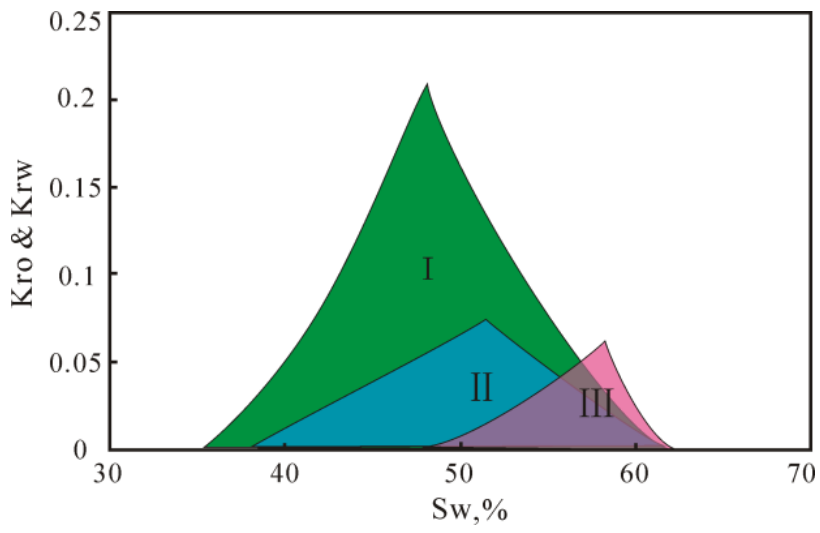

Figure 4: Comparison of the oil-water two-phase co-flowing zone among different diagenetic facies

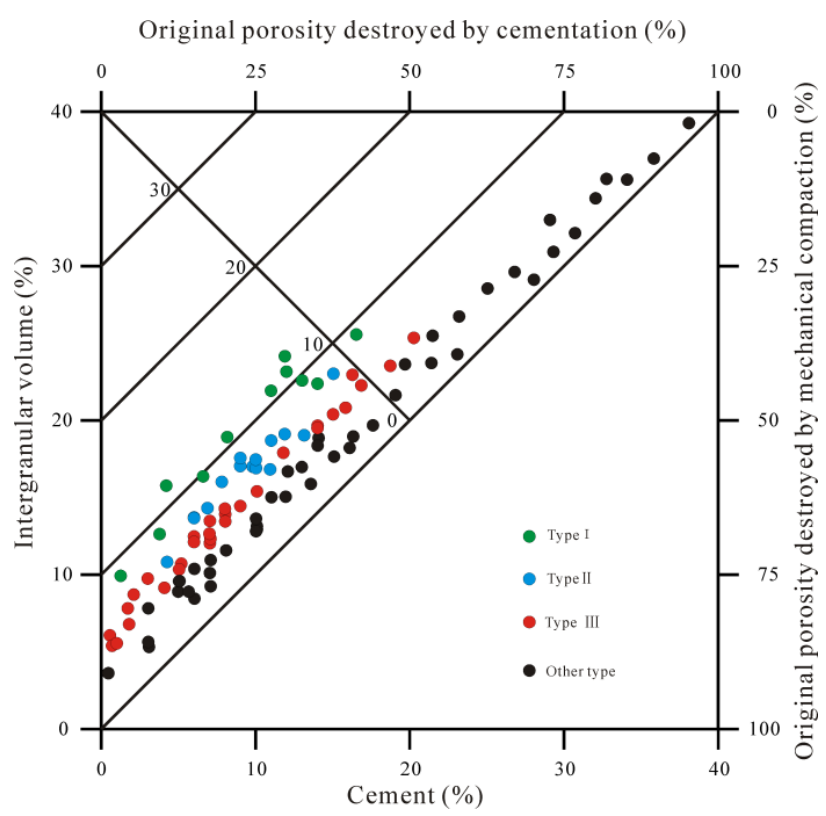

Figure 5: Plot of intergranular volume (IGV) vs. Cement volume and destruction of porosity by mechanical compaction vs. cementation.
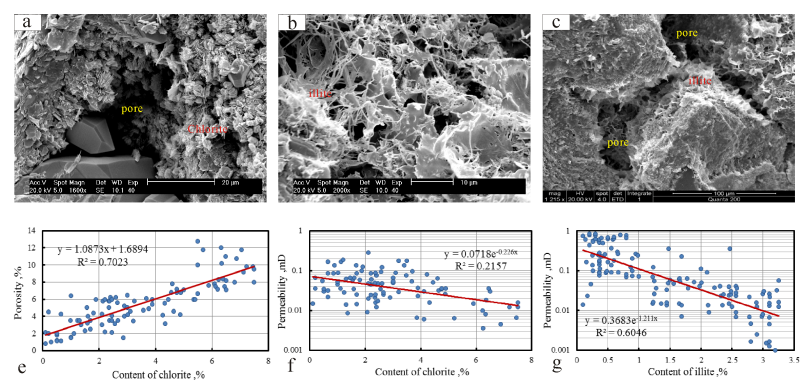

Figure 6: (a), (b) and (c): Microstructural characteristics of clay minerals. (e) and (f): Relationship between the content of chlorite and porosity/permeability. (g): Relationship between content of illite and permeability. erty, the stronger the interference of water on oil phase seepage. In all sandstones, when the water saturation exceeds $60 \%$, the crude oil will completely lose its flowing capacity.

3. The presence of chlorite and illite in the reservoir reduces the effective pore radius, increases the internal specific surface area of the sandstone, and enhances binding to the fluid, which is an important factor for the reduction of reservoir permeability.

Acknowledgement: We thank the PetroChina Changqing Oilfield Company for providing samples and access to the data. This work is financially supported by the National Natural Science Foundation of China (No.51674211) and Youth Software Creative Engineering from Technological Office of SiChuan Province (No.2018058).

\section{References}

[1] Zou, C., Yang, Z., Tao, S.Z., Yuan, X.J., Zhu, R.K., Hou, L.H., Wu, S.T., Sun, L., Zhang, G.S., Bai, B., Wang, L., Gao, X.H., Pang, Z.L., 2013. Continuous hydrocarbon accumulation over a large area as a distinguishing characteristic of unconventional petroleum: the Ordos basin, north-central China. Earth Sci. Rev. 126 (9), 358-369.

[2] Olson, J.E., Laubach, S.E., Lander, R.H.,2009.Natural fracture characterization in tight gas sandstones: integrating mechanics and diagenesis. AAPG Bull. 93(11), 1535-1549

[3] Rezaee, R., Saeedi, A., Clennell, B., 2012. Tight gas sands permeability estimation from mercury injection capillary pressure and nuclear magnetic resonance data. J. Pet. Sci. Eng. 88-89, 92-99.

[4] Ramstad, T., Idowu, N., Nardi, C., Øren, P.E., 2012. Relative permeability calculations from two-phase flow simulations directly on digital images of porous rocks. Transp Porous Media 94, 487504.

[5] Raeini, A.Q., Bijeljic, B., Blunt, M.J., 2015. Modelling capillary trapping using finitevolume simulation of two-phase flow directly on micro-CT images. Adv. water Resour. 83, $102 \mathrm{e} 110$.

[6] Loucks, R.G., Reed, R.M., Ruppel, S.C., Hammes, U., 2012. Spectrum of pore types and networks in mudrocks and a descriptive classification for matrix-related mudrock pores. AAPG Bull. 96, 1071-1098.

[7] Anovitz, L.M., Cole, D.R., 2015. Characterization and analysis of porosity and pore structures. Rev. Mineral. Geochem. 80 (1), 61-164

[8] Schmitt, M., Fernandes, C.P., Wolf, F.G., Neto, J.A.B.C., Rahner, C.P., 2015. Characterization of Brazilian tight gas sandstones relating permeability and angstrom-to micron-scale pore structures. J. Nat. Gas Sci. Eng. 27, 785-807.

[9] Bai, B., Zhu, R., Wu, S., Yang, W., Jeff, G., Allen, G., Zhang, X., Su, L., 2013. Multi-scale method of nano(micro)-CT study on microscopic pore structure of tight sandstone of Yanchang formation, Ordos basin. Pet. Explor. Dev. 40 (3), 329-333.

[10] Daigle, H., Thomas, B., Rowe, H., Nieto, M., 2014. Nuclear mag- 
netic resonance characterization of shallow marine sediments from the Nankai Trough, Integrated Ocean Drilling Program Expedition 333. J. Geophys. Res. 119, 2631-2650

[11] Zhao, P., Wang, Z., Sun, Z., Cai, J., Wang, L., 2017. Investigation on the pore structure and multifractal characteristics of tight oil reservoirs using NMR measurements: Permian Lucaogou formation in Jimusaer sag, Junggar Basin. Mar. Pet. Geol. 86,10671081.

[12] Shao, X., Pang, X., Jiang, F., Li, L., Huyan, Y., Zheng, D., 2017. Reservoir characterization of tight sandstones using NMR and IPMI experiments: implication for tight sand gas reservoir quality. Energy Fuel 31, 10420-10431

[13] Verges, E., Tost, D., Ayala, D., Ramos, E., Grau, S., 2011. 3D pore analysis of sedimentary rocks. Sediment. Geol. 234, 109-115.

[14] Lai, J., Wang, G.W., Wang, S., Cao, J.T., Li, M., Pang, X.J.2018. Review of diagenetic facies in tight sandstones: diagenesis, diagenetic minerals, and prediction via well logs. Earth-Science Reviews,185, 234-258.

[15] Kakouei, A., Masihi, M., Sola, B. S., \& Biniaz, E. 2014. Lithological facies identification in iranian largest gas field: a comparative study of neural network methods. Journal of the Geological Society of India,84(3), 326-334.

[16] Maurya, S. P., \& Singh, N. P. 2018. Application of lp and $\mathrm{ml}$ sparse spike inversion with probabilistic neural network to classify reservoir facies distribution - a case study from the blackfoot field, canada. Journal of Applied Geophysics, 159, 511-521.

[17] Wang, G., \& Carr, T.R.2012. Marcellus shale lithofacies prediction by multiclass neural network classification in the appalachian basin. Mathematical Geosciences, 44(8), 975-1004.

[18] Wang, G., Carr, T.R., Ju, Y., \& Li, C. 2014. Identifying organic-rich marcellus shale lithofacies by support vector machine classifier in the appalachian basin. Computers \& Geosciences, 64(3), 5260.

[19] Ma, C.L., R.J.Wang, B.L.Luo, W.B.Duan, C.Y.Feng, S.P.Wang, Y.X.Suo, Z.Z.Qiang 2012. Characteristics of Chang-8 Oil Reservoir and Distribution of Oil Reservoirs in Maling Oilfield, Ordos Basin. Natural Gas Geoscience. 23:514-519 (in Chinese with English abstract)

[20] Wang, M., M.Zeng, H,A.Chen, G.Yang, J.F.Xu, H.B.QIU, H.G.Guo, J.M.Wang 2017. Influencing factors of tight reservoirs and favorable diagenetic facies:a case study of Chang 8 reservoir of the Upper Triassic Yanchang Formation in Maling Oilfield, Ordos Basin. Lithologic Reservoirs, 29: 59-70 (in Chinese with English abstract).

[21] Yang,Y.X., Q.Huang, W.T.Liu, Q.Liu, B.Wang, Y.Wang 2015.Research of reservoir heterogeneity of shallow -water delta system,Ordos Basin:taking Chang 8 reservoir in Maling Oilfield as an example. Complex Hydrocarbon Reservoirs, 8:39-43 (in Chinese with English abstract).

[22] Wu, F.L., Li, W.H., Li, Y.H., Xi, S.L. 2004. Delta sediment sand evolution of the Yanchang formation of Upper Triassic in Ordos basin. Journal of Palaeo-geography. 6(3):307-315

[23] Luo, J.L., Li, Z.X., Shi, C.E., Li, J., Han, Y.L., Wang, H.H., Li, J.B., Li, Y.C.2008. depositional systems and provenance directions for the Chang 6 and Chang 8 reservoir groups of the Upper Triassic Yanchang Formation in the southwestern Ordos basin, China. Geologcal Bulletin of China, 27(1):101-111.

[24] Li, W.H., Pang, J.G., Cao, H.X., Xiao, L., Wang, R.G.2009. Depositional system and paleogeographic evolution of the late Triassic Yanchang Stage in Ordos Basin. Journal of Northwest university (natural gas edition) ,39(3):501-506.

[25] Wang, L., Li, W.H., Lin, T.,Wang, R.G.2012.Diagenesis and its influencing factors of the Chang 6 interval of Upper Triassic Yanchang Formation in Ordos Basin. Journal of Palaeogeography, 14(3):311-320

[26] Zou, C.N., L.Wang, Y.Li, S.Z.Tao, L.H.Hou 2012. Deep-lacustrine transformation of sandy debrites into turbidites, Upper Triassic, Central China. Sedimentary Geology. 265-266:143-155

[27] Yao, J.L.,Chu, M.J., Bai, C.E.,Yuan, X.M., Guo, Z.Q.2014. Sedimentary characteristics and genesis of thick layer sand body of Chang 82 sublayer in Ordos Basin. Lithologic Reservoirs,26(6):40-45

[28] Yang, W., Liu, L., Li, S., Ji, H., Xu, Z., \& Luo, Z., et al. 2017. The forming mechanism and process of tight oil sand reservoirs: a case study of chang 8 oil layers of the upper triassic yanchang formation in the western jiyuan area of the ordos basin, china. Journal of Petroleum Science \& Engineering, 158, 29-46.

[29] Grigsby, J.D., Langford, R.P., 1996. Effects of diagenesis on enhanced-resolution bulk density logs in Tertiary Gulf Coast sandstones: an example from the Lower Vicksburg Formation, McAllen Ranch field, south Texas. AAPG Bull. 80, 1801-1819.

[30] Zou, C.N., Tao, S., Zhou, H., Zhang, X., He, D., Zhou, C., Wang, L., Wang, X., Li, F., Zhu, R., 2008. Genesis, classification, and evaluation method of diagenetic facies. Pet. Explor. Dev. 35, 526540.

[31] Zeng, H.L., Zhu, X.M., Zhu, R.K., Zhang, Q.S., 2013. Seismic prediction of sandstone diagenetic facies: applied to Cretaceous Qingshankou Formation in Qijia Depression, Songliao Basin, East China. Pet. Explor. Dev. 40 (3), 287-295.

[32] Fu, G.M., Qin, X.L., Miao, Q., Zhang, T.J., Yang, J.P., 2009. Division of diagenesis reservoir facies and its control case study of Chang-3 reservoir in Yangchang Formation of Fuxian exploration area in Northern Shaanxi. Int. J. Min. Sci. Technol. 19 (4),537-543

[33] Ozkan, A., Cumella, S.P., Milliken, K.L., Laubach, S.E., 2011. Prediction of lithofacies and reservoir quality using well logs, Late Cretaceous Williams Fork Formation, Mamm Creek field, Piceance Basin, Colorado. AAPG Bull. 95 (10), 1699-1723

[34] Liu, H., Zhao, Y., Luo, Y., Chen, Z., He, S., 2015. Diagenetic facies controls on pore structure and rock electrical parameters in tight gas sandstone. J. Geophys. Eng. 12 (4), 587-600.

[35] Carvalho, A.D.S.G., De Ros, L.F., 2015. Diagenesis of Aptian sandstones and conglomerates of the Campos basin. J. Pet. Sci. Eng. 125, 189-200.

[36] Ran, Y., Wang, G., Lai, J., Zhou, Z., Cui, Y., Dai, Q., Chen, J., Wang, S., 2016. Quantitative characterization of diagenetic facies by using logging crossplot: a case study on Chang 7 tight sandstone oil reservoir in Heshui area, Ordos Basin. Acta Sedimentol. Sin. 34 (4), 694-706.

[37] Lai, J., Wang, G., Chai, Y., Ran, Y., 2016. Prediction of diagenetic facies using well logs: evidences from Upper Triassic Yanchang Formation Chang 8 sandstones in Jiyuan Region, Ordos Basin, China. Oil Gas Sci. Technol. 71, 34.

[38] Nabawy, B.S., Géraud, Y., Rochette, P., Bur, N., 2009. Porethroat characterization in highly porous and permeable sandstones. AAPG Bull. 93 (6), 719-739.

[39] Müller-Huber, E., Schön, J., Börner, F., 2016. Pore space characterization in carbonate rocks-approach to combine nuclear magnetic resonance and elastic wave velocity measurements. J. Appl. Geophys. 127, 68-81.

[40] Torabi, F., Mosavat, N., Zarivnyy, O., 2016. Predicting heavy 
oil/water relative permeability using modified Corey-based correlations. Fuel 163, 196-204.

[41] Zhang, N., Yan, B., Sun, Q., Wang, Y., 2017. Improving multiscale mixed finite element method for flow simulation in highly heterogeneous reservoir using adaptivity. J. Petrol. Sci. Eng. 154, 382-388.

[42] Paxton, S.T., Szabo, J.O., Ajdukiewicz, J.M., Klimentidis, R.E., 2002. Construction of an intergranular volume compaction curve for evaluating and predicting compaction and porosity loss in rigid-grain sandstone reservoirs. The American Association of Petroleum Geologists Bulletin 86, 2047-2067.

[43] Salem, A. M. (2005). Diagenesis and reservoir-quality evolution of incised-valley sandstones: evidence from the abu madi gas reservoirs (upper Miocene), the Nile delta basin, Egypt. Journal of Sedimentary Research, 75(4), 572-584.
[44] Beard, D.C., Weyl, P.K., 1973. Influence of texture on porosity and permeability of unconsolidated sand. AAPG Bull. 57:349369

[45] Ehrenberg, S.N., Nadeau, P.H., 1989. Formation of diagenetic illite in sandstones of the Garn Formation, Haltenbanken area, mid-Norwegian continental shelf. Clay Minerals 24, 233-253.

[46] Zheng, Q.H., Y.Q.Liu 2015. The Diagenesis and Diagenetic Lithofacies of Tight Reservoir of Chang $4+5$ Member of Yanchang Formation in Huaqing Area, Ordos Basin. Advances in Earth Science, 30:78-89 (in Chinese with English abstract). 